UDC 371.13:504(008)

DOI https://doi.org/10.32838/2663-6069/2020.1-2/04

Balatska L. P.

Lviv Polytechnic National University

Vyslobodska I. M.

Lviv Polytechnic National University

\title{
NEEDS ANALYSIS IN TEACHING ENGLISH FOR SPECIFIC PURPOSES
}

The article focuses on the definition of a term "needs analysis", its practical purposes and research instruments to be used in the procedure. Needs analysis involves doing some kind of activity with a learner in order to find out what their learning needs are. It is considered to be the most important stage of curriculum design and teaching English for Specific Purposes (ESP).

The purpose of conducting needs analysis in ESP involves collecting and collating relevant information about a single learner's or a set of learners' common purposes for learning English, and interpreting the data so that choices and decisions can be made about defining objectives and principles for course design and materials.

In the paper the following steps for conducting needs analysis have been proposed: to define the purpose, to delimit target population, to delimit parameters of investigation, to collect data, to analyze results, to interpret results, to critique the project. While performing needs analysis different kinds of research instruments can be used: questionnaires, self-ratings, interviews, meetings, observations, collecting learner language samples, task analysis, case studies, analysis of available information.

We identify needs analysis as one of the professional development topics. It's worth mentioning that the language competence and learning needs of the students should be analyzed at different stages: initially, while designing an ESP course and during the course to make adjustments and improvements. Only after analyzing the learners' needs and determining the objective of the language course, you can select teaching materials that best suit the needs of all the participants of a learning process. It is the foundation, on which you can develop curriculum content, educational tasks and methords that can lead to increasing the learners' motivation and success.

Today needs analysis should not be of concern only within the field of ESP, but also that of General English, because the needs of the learners is of paramount importance in any language course.

Key words: needs analysis, English for Specific Purposes, learning needs, language competence, curriculum design.

Formulation of the problem. The notion of needs analysis is concerned with the activities involved in collecting the necessary information for developing an effective curriculum that meets learners' particular needs. Only after analyzing the learners' needs and determining the objectives of the language course, you can select teaching materials that best suit the needs of all the participants of a learning process. Thus, needs analysis is the foundation on which you can develop curriculum content, educational tasks and methods, that can lead to increasing the learners' motivation and autonomy.

Analysisof therecentresearchandinvestigations. Needs analysis procedure in the field of language teaching was first used by Michael West in a survey report published in 1926 [8, p. 157]. In the next decades little if any attention was given to needs analysis. This was caused mainly by the influence that the traditional structural view of the language continued to exert on the field of English language teaching. The term "needs analysis" re-emerged during the 1970's as a result of the emergence of the communicative approach to language teaching.

A number of linguists (R. Berwick [1], T. Hutchinson [2], A. Johns [4], Li Juan [5], N. Schutz [6], R. West [7], etc.) laid emphasis on needs analysis as an insinuating point for devising syllabuses, courses, material for specific audiences. All of them acknowledged a vital role and centrality of needs analysis in the process of designing and carrying out any language course whether it be English for Specific Purposes (ESP) or general English. In his "State of the Art" article, R. West [7] gives a thorough overview of needs analysis in 
language teaching, including its history, theoretical basis, approaches to needs analysis, etc.. According to T. Iwai et al [3], the term "needs analysis" generally refers to the activities that are involved in collecting information that will serve as the basis for developing a curriculum that will meet the needs of a particular group of students. The scholar also mentions that formal needs analysis is relatively new to the field of language teaching. However, informal needs analyses have been conducted by teachers in order to assess what language points their students needed to master. For A. Johns [4], needs analysis is the first step in course design and it provides validity and relevancy for all subsequent course design activities. Clearly, the role of needs analysis in any ESP course is indisputable.

The purpose of the paper. Under the guidance of a needs analysis theory, this article aims at providing a clear definition of the term "needs analysis", setting its practical purposes, and determining the procedures of its implementation.

Presentation of the basic material. Needs analysis is the most important stage of ESP teaching and is a widely used tool to study the validity and relevancy of all curriculum design activities. It assures a flexible curriculum responsive to the needs of various participants of education. Curriculum design is a process during which the basic principle of a teaching plan is conveyed, supervised and put into practice $[5$, p. 1873]. Needs analysis involves doing some kind of activity with a learner in order to find out what their learning needs are. Moreover, a good understanding of learner needs can contribute to successful course planning. Macmillan Dictionary [9] provides a definition of a needs analysis as the process of defining what a language learner's needs are in order to design a course for them.

Berwick [1, p. 52] suggests a basic definition of need: a need is a "gap or measurable discrepancy between a current state of affairs and a desired future state". Needs analysis is a complex process which has to take into account what Hutchinson and Waters [2] define as " target needs", what learners need to do in the target situation (i.e. language use) and "learning needs", what learners need to do in order to learn (i.e. language learning). So, learning needs refer to the background linguistic knowledge the learner needs to have in order to master the further abilities he will need to perform in the target situation. We take the view that we shouldn't only take into account "target needs" and "learning needs" (i.e. objective needs), but also learners' affective needs, such as their interests, wishes, expectations and preferences (i.e. subjective needs). Needs analysis is a systematic process used to determine where gaps exist between current performance and desired performance. The teachers designing the ESP course are compelled to begin from analyzing learners' particular needs and demands. A well-established curriculum design should first have a thorough investigation of the needs of learners, teaching organization and the society [5, p. 1873].

Theneedsanalysisdonebyeachindividualinstitution should include an analysis of the a) requirements of the educational and qualification characteristics of graduates adopted by the Ministry of Education and Science of Ukraine; b) specific job descriptions developed and validated by businesses, institutions and organizations; c) results of a survey carried out among professionals, teachers and students of higher educational institutions [10, p. 50].

Needs analysis in language teaching may be used for a number of different purposes. For example, to find out what language skills a learner needs in order to perform a particular role such as sales manager, tour guide, or university student; to help determine if an existing course adequately addresses the needs of potential students; to determine which students from a group are most in need of training in particular language skills; to identify a change of direction that people in a reference group feel is important; to identify a gap between what students are able to do and what they need to be able to do; to collect information about a particular problem learners are experiencing.

The purpose of conducting needs analysis in ESP involves collecting and collating relevant information about a single learner's or a set of learners' common purpose(s) for learning English, and interpreting the data so that choices and/or decisions can be made about defining objectives and principles for course design and materials. Data collection devices include questionnaires, self-ratings, interviews, meetings, observation, collecting learner language samples, task analysis, case studies, analysis of available information. When conducting needs analysis, a variety of procedures can be used and the type of procedures selected determines the information acquired. Schutz and Derwig [6] offered eight elaborative steps to conduct a needs assessment. They are: to define the purpose, delimit target population, to delimit parameters of investigation, to collect data, to analyze results, to interpret results, and to critique the project.

Defining the purpose involves identifying the goals of the study precisely in order to achieve useful results.

Delimiting the target population refers to defining the target population of the study in order to make practical decisions about monetary, position and time considerations. 
Delimiting the parameters of investigation includes the planning of the limitations of the study in order to raise its effectiveness.

Selecting the information gathering instrument refers to choosing the appropriate data collection instruments. Selecting the information gathering instruments depends on the conditions, scope and objectives of the study.

The collection of the data is directly related to the data collection instruments that will be used in this procedure. Different types of data gathering instruments, such as distributing questionnaires, conducting interviews, doing observations require different processes to follow up. A questionnaire is any written instrument that presents respondents with series of questions or statements to which they are to react either by writing out their answers or selecting from among existing answers.

A needs analysis questionnaire is often a good way of finding out about your students' English language experience, their current level of English and their English language requirements. When creating a needs analysis questionnaire, it is best to use "open question forms" such as What...? Why...? How...? When...? rather than "closed forms" which are likely to result in only "yes" and "no" answers. A needs analysis questionnaire can contain the following questions: What experience do you have of learning English? When do you normally use English? Who do you communicate in English with? What are your main three reasons for learning English? What do you find most difficult when learning English? (e. g. speaking, writing, reading, listening). By studying the answers to needs analysis questionnaire, the teacher can see exactly where the student requires the most help relevant to their studies and individual life.

Interviews allow a more in-depth exploration of issue and may be useful at the preliminary stage of designing a questionnaire. Meetings allow a large amount of information to be collected in a fairly short time. Observation may either involve counting the number of times that a particular phenomenon occurs, such as how often a particular word is used in interviews. Language samples may be collected through written or oral tasks, simulations or role plays, performance and achievement tests.

Analyzing the results, the researcher may benefit either from computer-assisted analysis techniques or the observations and interpretations. Using computer-assisted analysis techniques to analyze data is more reasonable for the sake of time and effort, compared with observations and interpretations that require extended contact with the target situations and qualitative interpretations of the data.
In the interpretation of the results section, the researcher explores what he/she had derived from the process of data interpretation. There the researcher attempts to draw implications about the learners' language needs by using the data analysis results.

Finally, the critique of the project section includes drawing out implications for further studies and explains the limitations of the study [5, p. 1873].

The language competence and learning needs of the students should be analyzed at different stages: initially, while designing an ESP course, and during the course to make adjustments and improvements. Different kinds of research instruments can be used to identify the students' needs: interviews (face-to-face or written interviews, the last being of more value to the process of teaching), questionnaires (perhaps followed by an interview), and observations (job and on-going study ones), etc. [10, p. 50].

At the end of each month or term, teachers and students can re-visit the needs analysis as a benchmark to compare the starting point against the student's progress. You can then see how close they are to their target competency level.

It is also important to conduct new needs analyses occasionally as student needs and goals can change. Perhaps, they have a new activity which requires them to talk to customers or use specific vocabulary, for example related to education, finance, beauty or sport.

When measuring the needs of students it can be useful to give an area of knowledge a "measurement of need" using a scale of 1 to 5 from least important to most important. For example, considering the need of writing skills you could consider essay writing, business writing, report writing, letter writing, and social writing for emails and letters to friends. If a student is working in an office where they need to answer the telephone in English, but their needs analysis questionnaire also states that they aren't speaking confidently on the phone, their need to improve speaking skills would be ranked as 5 - very important. Another example could be a student who has to write essays at university. Their need would be high (ranked as 5), for essay writing skills. Their classes should focus strongly on improving writing skills within an academic context.

Conclusions and prospects of further investigations. Performing needs analysis can be an excellent way for EFL teachers to find out more about their students and make devising classes for them much easier. It is also helpful to find out about students motivation, their prior learning experiences, the situations they are likely to use English in, which skills and language items they need to extra practice with. Armed with this information, the teacher can select and create the most appropriate and useful learning materials and activities. 
Besides when you know the students' needs and their current ability level, it is possible to identify the knowledge gaps and set targets for their progress. The needs analysis can be used as you formulate the classes so that each semester moves the student a step closer to their target level in each language learning skills (reading, writing, speaking and listening).
We identify needs analysis as one of the professional development topics. Needs analysis is part of building learner awareness and autonomy. It can encourage them to start thinking about their learning and taking responsibility for it. Today needs analysis should not be of concern only within the field of ESP, but also that of General English because the needs of the learners are of paramount importance in any language process.

\section{References:}

1. Berwick R. Needs assessment in language programming: from theory to practice. In: Johnson, R. K. (Ed). The second language curriculum. Cambridge : Cambridge University Press, 1989. P. 46-62.

2. Hutchinson T., Waters A. English for Specific Purposes. Cambridge : Cambridge University Press, 1987. $183 \mathrm{p}$.

3. Japenese language needs analysis / T. Iwai et al. 1999. URL: http://www.nf/rc. hawaii. edu/Networks/ NW13/NW13

4. Johns A. English for specific purposes: Its history and contribution ; Celce-Murcia M. (Ed.). Teaching English as a second or foreign language. Boston, MA : Heinle @Heinle, 1991. P. 67-77.

5. Juan Li. Needs Analysis: An Effective Way in Business English Curriculum Design. Theory and Practice in Language Studies. ACADEMY PUBLISHER, 2014. Vol. 4. № 9. P. 1869-1874.

6. Schutz N. W., Derwing B. I. The Problems of needs assessment in English for specific purposes: Some theoretical and practical considerations. In R. Mackay J. D. Palmer. Language for specific purposes. Program Design and Evaluation. Rowley MA : Newbury House, 1981. P. 29-45.

7. West R. ESP - State of the art. URL: www.man.ac.Uk/CELSE/esp/west.htm

8. White Ronald V. The ELT Curriculum Design. Innovation and Management. Oxford : Basil Blackwell. Canadian Modern Language Review 49 (1), 1988. P. 157-159.

9. Macmillan Dictionary. URL: https:/www.Macmillan-dictionary/com/dictionary/british/needs-analysis

10. Програма 3 англійської мови для професійного спілкування / Г. Є. Бакаєва та ін. Київ : Ленвіт, 2005. $119 \mathrm{c}$.

\section{Балацька Л. П., Вислободська І. М. АНАЛІЗ ПОТРЕБ \\ У ВИКЛАДАННІ АНГЛІЙСЬКОЇ МОВИ ДЛЯ СПЕЦІАЛЬНИХ ЦІЛӖ}

Стаття досліджує визначення терміна “аналіз потреб”, практичну мету та дослідницькі засоби його проведення. Аналіз потреб передбачає виконання певного виду діяльності зі студентами з метою виявлення їхніх навчальних потреб. Вважають, ще аналіз потреб є найважливішим етапом в укладанні навчальних програм та у викладанні англійської мови для спеціальних иілей.

Мета проведення аналізу потреб з англійської для спеціальних иілей є збір та впорядкування відповідної інформачії про спільну потребу для вивчення англійської одним студентом чи групою студентів та інтерпретація отриманих результатів з метою визначення цілей та принципів розробки навчального курсу та матеріалів.

У статті запропоновано поетапні кроки проведення аналізу потреб: визначення мети, обмеження цільових учасників, обмеження параметрів дослідження, збір даних, аналіз отриманих результатів, їх обтрунтування, критичний огляд проекту. При иьому є иирокий вибір досліднищьких засобів: анкетування, саморейтингування, співбесіди, зустрічі, спостереження, збір робіт студентів, аналіз завдань, вивчення окремих ситуачій, аналіз отриманої інформачії.

Ми визначаємо аналіз потреб як одну з тем для професійного розвитку викладача. Слід зазначити, що мовленнєва компетенція та аналіз потреб студентів можуть визначатися на різних етапах навчального процесу: на початку під час укладання курсу англійської для спеціальних иілей та під час викладання курсу зметою внесення доповнень та вдосконалень. Тільки після визначення навчальних потреб та чілей мовного курсу можсливо відібрати навчальні матеріали, які найкраще відповідатимуть вимогам усіх учасників навчального процесу. Це основа, на якій можливо побудувати зміст навчальної програми, навчальних завдань та методів, що призведуть до зростання студентської мотиваиії та успіху.

Сьогодні аналіз потреб повинен стосуватися не лише англійської мови для спеціальних иілей, а й загальної англійської, оскільки аналіз навчальних потреб студентів є пермочерговим завданням під час викладання будь-якого мовного курсу.

Ключові слова: аналіз потреб, англійська для спеціальних иุілей, навчальні потреби, мовленнєва компетенція, укладання навчальних програм. 